\title{
HIF-mediated endothelial response during cancer progression
}

\author{
Colin E. Evans • Cristina Branco-Price • \\ Randall S. Johnson
}

Received: 26 March 2012/Revised: 30 March 2012/ Accepted: 2 April 2012/Published online: 8 May 2012

(c) The Japanese Society of Hematology 2012

\begin{abstract}
Tumour growth at primary or secondary extravasation sites leads to localised regions of reduced oxygen tension (hypoxia) in cells both within and surrounding the tumour. Although the angiogenic response of the tumour cell to hypoxia has been widely examined, the effect of hypoxia on other cell types within the tumour microenvironment is less clear. The endothelium is highly responsive to local hypoxia and regulates tumour cell dissemination and ultimately metastatic success through differential regulation of hypoxia-inducible transcription factors (HIFs). The endothelial response to hypoxia particularly mediates key processes that regulate tumour vascularisation and cancer progression, including proliferation, migration, adherence, and vascular permeability. This article describes current understanding of the HIF-mediated endothelial response to hypoxia during cancer progression. Endothelial HIF signalling regulates tumour growth and metastasis and is therefore an attractive putative target for treatments that inhibit cancer progression.
\end{abstract}

Keywords Cancer $\cdot$ Endothelial $\cdot$ Hypoxia $\cdot$ Metastasis

\section{Introduction}

Solid tumours and metastases are characterised by accelerated proliferation rates and insufficient oxygen delivery from the host vasculature, which lead to localised regions of hypoxia in cells within and surrounding the tumour. Hypoxia stimulates new vessel formation in an attempt to

C. E. Evans · C. Branco-Price · R. S. Johnson ( $\square)$

Department of Physiology, Development and Neuroscience, University of Cambridge, Cambridge, CB2 3EG, UK e-mail:rsj33@cam.ac.uk restore blood flow and facilitate continued tumour growth. The remodelling response that follows hypoxia is controlled primarily by the hypoxia-inducible transcription factors (HIFs), which consist of an oxygen-regulated $\alpha$ subunit and a constitutively expressed $\beta$ subunit. Hypoxia and HIF activation are strongly associated with increased malignancy, decreased therapeutic response, and unfavourable clinical outcome [1]. The endothelium is ideally placed to respond to changes in local oxygenation and mediate physiological and pathological vascular response to hypoxia. The effect of endothelial hypoxia on tumour growth and metastasis is therefore crucial and this article describes the endothelial HIF-mediated response that occurs during cancer progression.

\section{Oxygen-dependent regulation of endothelial HIF}

Tumour and endothelial hypoxia stimulate cellular responses that mediate tumour progression and metastasis. These hypoxia and HIF-mediated effects on tumour growth and metastasis are time, isoform, and cell type dependent $[2,3]$. The hypoxia-dependent $\alpha$ subunit of HIF [1] is highly expressed in breast tumour and adjacent endothelial regions [4], and endothelial HIF signalling regulates vascular development in mouse embryos [5] and metastasis in mouse models of breast cancer [2]. Endothelial cells also form the barrier between primary tumours and secondary sites of extravasation and are therefore ideally located to respond to local hypoxia. The endothelium can regulate the remodelling response to hypoxia primarily via the activation of HIF1 and 2. HIF $1 \alpha$ is hydroxylated under normoxia by prolyl hydroxylase domain (PHD) enzymes, which allows binding with the E3 ubiquitin ligase complex and subsequent proteosomal degradation (Fig. 1). Also during normoxia, HIF1 $\alpha$ 
Fig. 1 Oxygen-dependent degradation of HIF1 alpha. a Under normoxia PHDs hydroxylate prolyl residues 402 and 564, and FIH hydroxylates asparaginyl residue 803 . b This allows binding of the VHL complex, which targets HIF1 $\alpha$ for proteosomal degradation, and prevents interaction of HIF1 $\alpha$ with coactivators p300/ CBP
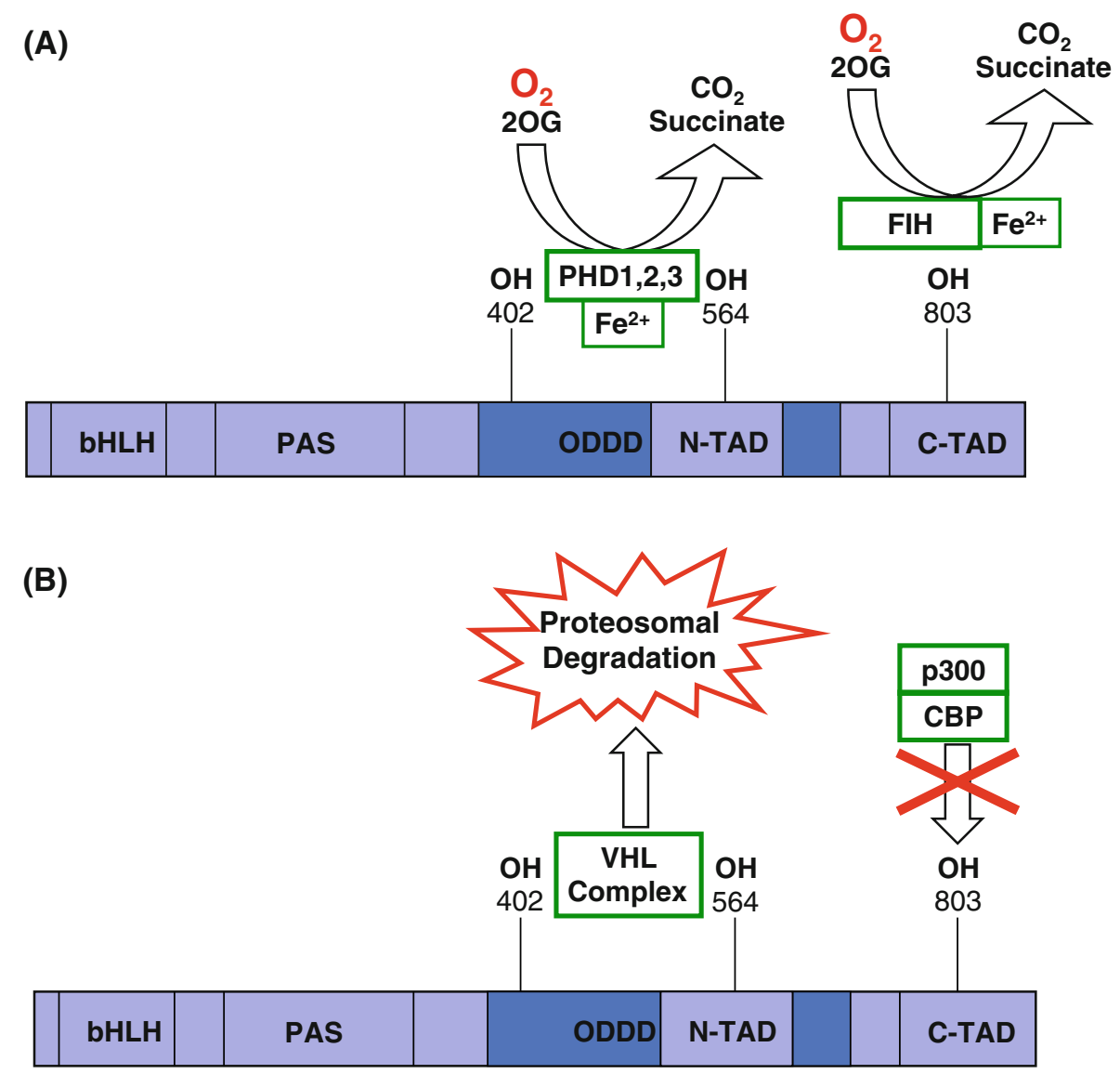

hydroxylation by factor inhibiting HIF (FIH) prevents interaction of HIF1 $\alpha$ with its transcriptional co-activators p300 and Creb binding protein (CBP). During hypoxia, however, PHD and FIH substrate availability is limited, which reduces their activity and allows HIF $1 \alpha$ to accumulate. Stable HIF $1 \alpha$ translocates to the nucleus, where it dimerises with the constitutively expressed HIF $1 \beta$ subunit and forms the active HIF1 complex. Binding of HIF1 to the hypoxiaresponsive element (HRE) induces transcriptional upregulation of a catalogue of target genes that modulate tumour vascularisation and growth. A greater understanding of the mechanisms that regulate the remodelling response to endothelial hypoxia during cancer progression may ultimately lead to the development of novel adjunctive cancer treatments.

\section{Endothelial response to hypoxia during cancer progression}

Endothelial HIF signalling upregulates inflammatory cytokines and growth factors that mediate tumour vascularisation and growth [6]. Hypoxic activation of endothelium also increases cell adhesion, coagulant properties, and endothelial permeability, which are crucial for the processes of intravasation and extravasation that together result in metastasis [2, 7].

Tumour vascularisation and growth

Diffusion distances from tumour cells to the vasculature increase as these cells rapidly proliferate and the tumour develops. The resulting reduction in regional blood flow leads to localised hypoxia, which in turn stimulates neovascularisation that is essential to provide adequate oxygenation of proliferating tumour cells and support tumour growth. Endothelial cells establish this vascular network and these cell types are essential, given that one endothelial cell regulates the survival of approximately 50-100 tumour cells [8]. The transcriptome of endothelial cells in tumour compared with normal adjacent tissue is also substantially different [9-11] and cell proliferation is approximately 20 to 2000-fold greater [12]. Tumour endothelium is therefore an attractive target for anti-angiogenic treatments that impair tumour growth [13]. Hypoxia increases endothelial cell migration, tube formation [14], and capillary density [15] in a time-dependent manner. These acute or chronic responses are controlled via HIF-induced production of growth factors and cytokines that regulate vascular remodelling and tumour growth. 


\section{Acute response}

Acute hypoxia rapidly activates endothelial release of a variety of inflammatory cytokines, which increases recruitment and adherence of activated neutrophils to the endothelial wall [16]. Endothelial hypoxia initiates inflammation via upregulation of $\mathrm{P}$ - and E-selectins, which regulate inflammatory cell adhesion and migration [6]. E-selectin is hypoxia-inducible and increases leucocyte adhesion to the endothelium [17]. Hypoxic upregulation of intercellular adhesion molecule (ICAM) 1 and vascular cell adhesion molecule (VCAM) 1 in endothelial cells also increases neutrophil adherence to the endothelium [18]. Interleukin (IL) 1 is expressed by hypoxic endothelial cells, which further stimulates ICAM1 [17, 19], and in turn further increases leucocyte recruitment and adhesion [20]. Endothelial cells under hypoxia also release IL8, which similarly increases neutrophil recruitment and activation [21]. Endothelial hypoxia also leads to upregulation of extracellular matrix proteins that regulate the degradation of surrounding tissue and therefore facilitate vascular remodelling. These include matrix metalloproteinase 9 (MMP9) [22], which degrades type IV collagen, and other matrix proteins [23] that together facilitate neovascularisation.

\section{Chronic response}

Sustained endothelial hypoxia stimulates upregulation of a catalogue of other HIF-mediated angiogenic growth factors that promote vascularisation. These include but are not limited to platelet-derived growth factor (PDGF), placental growth factor (PLGF), insulin-like growth factor (IGF), basic fibroblast growth factor (bFGF), vascular endothelial growth factor (VEGF), thrombospondin, and monocyte chemotactic protein (MCP) 1 [22]. PDGF is produced by endothelial cells and enhances smooth muscle cell proliferation, which is essential for neovascularisation [22]. PDGF can also induce endothelial expression of other angiogenic growth factors such as VEGF [24]. PLGF is another member of the VEGF family that is produced by endothelial cells. PLGF can promote tumour vascularisation by; (1) stimulating the growth, migration, and survival of endothelial cells directly via VEGF receptor (VEGFR) 1 [25]; (2) recruiting monocytes; (3) mobilising endothelial progenitors [26]; and (4) increasing the expression of other angiogenic factors including bFGF, PDGF, and VEGF [2729]. FGF [30] and IGF [31] are also angiogenic mitogens with important roles in vessel growth. VEGF is another highly potent angiogenic growth factor produced by endothelial cells [32]. Tumour vascularisation and growth may be enhanced by endothelial VEGF in a number of ways. VEGF: (1) stimulates angiogenesis locally by increasing endothelial proliferation and migration [33]; (2) upregulates urokinase- and tissue-type plasminogen activator (UPA and tPA) activity in endothelial cells, which increases local fibrinolysis [34]; (3) increases endothelial cell survival or mobilises endothelial progenitors [35, 36]; (4) recruits monocytes and neutrophils [37]; and (5) activates monocytes to produce growth factors that are important for neovascularisation [38]. Thrombospondin is an endothelial cell-expressed matrix-associated protein [39], which may regulate angiogenesis via affecting platelet aggregation [40] and endothelial cell adhesion, proliferation, and migration [41]. Endothelial expression of the potent chemoattractant for monocytes, MCP1, is also enhanced by hypoxia [42].

The importance of endothelial HIF signalling during tumour vascularisation and growth has been highlighted using mice with endothelium-specific HIF $\alpha$ knockout generated by bone marrow reconstitution of mice lacking HIF $1 \alpha$ or HIF $2 \alpha$ in myeloid and endothelial cells driven by the Tie 2 promoter [43] or mice with endothelial cell-specific deletion of HIF $2 \alpha$ under the control of the VE-cadherin promotor [44]. Endothelial loss of HIF $1 \alpha$ in mouse models of breast cancer dramatically impairs angiogenic potential as shown by reductions in: (1) VEGF expression; (2) proliferation; (3) migration; (4) extracellular matrix penetration; (5) tube formation; (6) wound healing; (7) tumour vascularisation; and (8) tumour size [43]. Endothelial HIF2 $\alpha$ deletion increased cell migration and invasion in vitro and nonfunctional vessel formation and growth in an autochthonous skin tumour model [44]; while knockout of endothelial HIF $2 \alpha$ reduced tumour angiogenesis and growth in a subcutaneous xenograft model [45]. These findings demonstrate the crucial requirement for endothelial HIF signalling during tumour vascularisation and growth and identify endothelial HIF $1 \alpha$ and HIF $2 \alpha$ as potential targets for cell-directed antiangiogenic cancer treatments.

\section{Metastasis}

In addition to supporting tumour growth, the tumour vasculature provides the primary entry route for tumour cells into the circulation [46], and up to 2 million tumour cells enter the circulation per cubic centimetre of primary tumour [47]. Tumour endothelial cells produce many HIFmediated factors that regulate angiogenesis in the primary tumour and sites of metastatic dissemination, and highly vascularised tumours give rise to greater tumour cell entry into the blood [46]. Given that tumour cell entry into the blood is proportional to metastasis, it follows that greater tumour vascularisation leads to enhanced metastasis [46]. Endothelial HIF signalling is also a crucial mediator of metastasis, given that endothelial cells provide the barrier across which tumour cells travel from the primary tumour into the circulation and from the bloodstream into 
surrounding tissue. Endothelial HIF signalling can mediate these processes of intravasation and extravasation via affects on coagulant function and vascular permeability.

\section{Coagulant function}

Normoxic endothelial cells suppress coagulation and inflammation, and in doing so maintain a local fibrinolytic and anti-thrombotic state [48]. Conversely, stressors such as mechanical disturbance by tumour formation and tumour hypoxia activate the endothelium and this leads to upregulation of HIF-mediated coagulant and thrombotic factors including platelet-activating factor (PAF), tissue factor (TF), and plasminogen activator inhibitor (PAI) 1 [48, 49]. Hypoxic activation of endothelial cells could promote metastasis by: (1) increasing PAF-induced activation of platelets, which promote tumour cell survival at the site of metastasis [50]; and (2) increasing angiogenesis via TF-induced VEGF expression [51]. Hypoxia also reduces endothelial expression of the anti-coagulant thrombomodulin and increases endothelial cell coagulant activity $[6,7,52]$. Circulating tumour cells arrest in the capillary bed and adhere to the endothelium during extravasation. This vascular blockage is likely to result in localised hypoxia of tumour and endothelial cells. Endothelial hypoxia stimulates thrombus formation [53], which is itself a hypoxic stimulus that leads to upregulation of HIF $1 \alpha$, and a variety of HIF target genes that mediate tumour development and metastasis [54]. Thrombosis could support extravasation furthermore by: (1) providing a fibrin scaffold for tumour cell migration and binding of angiogenic factors such as VEGF [55], which together enhances metastatic success [56, 57]; and (2) protecting arrested tumour cells from endothelial detachment [58] and elimination by natural killer cells [59, 60]. Conversely, release of coagulant factors from hypoxic tumour endothelium may partly explain the strong association between cancer progression and thrombosis [61].

\section{Vascular permeability}

Hypoxia increases endothelial intracellular gaps, capillary permeability [6], and molecular transport through endothelial monolayers [7]. These effects could be mediated by VEGF and are likely to facilitate metastasis. VEGF is a vascular permeability factor whose endothelial expression is increased by hypoxia and HIF stabilisation. VEGF increases vascular permeability and this could increase metastasis by: (1) generating gaps between endothelial cells, which enables intravasation of tumour cells [62]; and (2) increasing interstitial fluid pressure, which is associated with increased metastasis [63]. Acute endothelial hypoxia also leads to transcriptional upregulation of other vasoactive substances involved in modulating vascular tone. These include vasoconstrictors and smooth muscle mitogens such as endothelin 1 and thrombospondin 1 [22]. Chronic endothelial hypoxia increases the expression of vasodilatory factors such as endothelial nitric oxide synthase (eNOS) and HIF directly regulates hypoxic induction of NOS in endothelial cells [64]. The vasodilatory NOS product nitric oxide (NO) acts directly on smooth muscle cells and indirectly facilitates vasodilation by inhibiting the actions of hypoxia-induced vasoconstrictors. Endothelial NO also facilitates tumour vascularisation by: (1) inducing relaxation of adjacent smooth muscle cells [65]; (2) inhibiting platelet aggregation and adhesion [66]; (3) regulating smooth muscle cell and fibroblast mitosis [67, 68]; (4) inhibiting endothelial apoptosis [69]; and (5) promoting endothelial proliferation [70]. Endothelial NO also modulates the hypoxic induction of other vasoactive factors such as endothelin 1 and therefore creates a reciprocal feedback loop [71]. Another positive feedback loop is created between HIF1 $\alpha$ and reactive oxygen species (ROS), whose endothelial production is increased during hypoxia [72], which in turn inhibits PHD activity and therefore increases HIF1 $\alpha$ expression [73-75].

The importance of endothelial HIF/VEGF/NO signalling during metastasis was comprehensively shown in mice with endothelial HIF deletion [2]. Endothelial HIF1 $\alpha$ knockout in mouse models of breast cancer dramatically impairs metastatic progression and reduces: (1) NO synthesis; (2) VEGF expression; (3) tumour cell migration through endothelial layers; and (4) pulmonary metastasis. Conversely, endothelial loss of HIF $2 \alpha$ has the opposite effect in each case. These findings identify endothelial HIF signalling as a crucial regulator of metastasis and demonstrate opposing roles for the HIF isoforms in regulating malignancy. This study highlights the importance of isoform- and cell-specific HIF targeting in the development of novel treatments that aim to suppress metastasis.

\section{Future perspectives}

Localised hypoxia occurs in tumours and occlusive thrombi and the endothelial HIF-mediated response is integral to both tumour and thrombus development, but mechanisms that regulate the association between thrombus formation and metastatic success remain unclear [56, 57, 60]. HIF-mediated endothelial response to thrombus formation may induce a catalogue of factors that control cancer progression, including VEGF and NO, which enhance tumour cell transport across endothelial monolayers and increase metastatic success [2]. Conversely, hypoxic endothelial cells within tumours release coagulants and other cytokines that increase thrombus formation, 


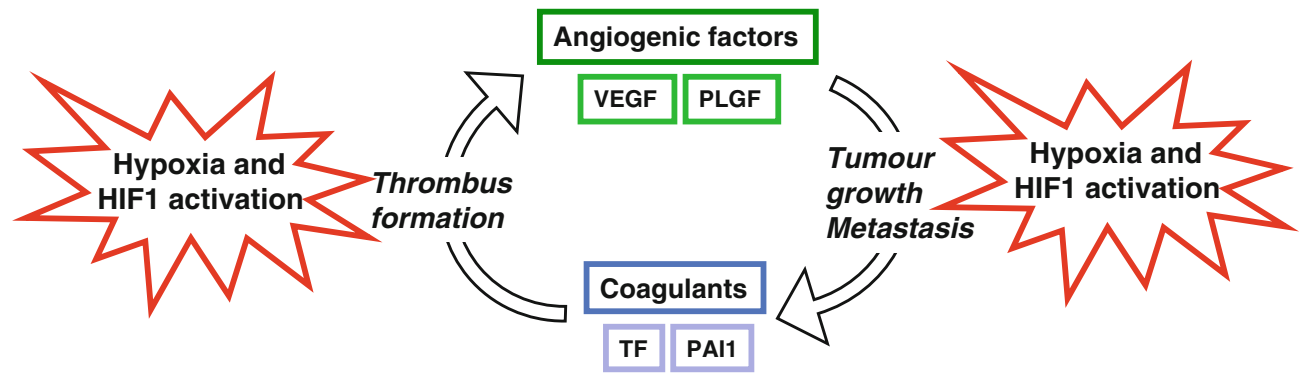

Fig. 2 Proposed mechanism of regulation of thrombosis-associated cancer progression. Thrombus formation stimulates a HIF-mediated hypoxic response in endothelial cells, which leads to expression of angiogenic factors, and in turn increases tumour growth and

such as TF and PAI1 [61]. Taken together these events create a positive feedback loop (Fig. 2) that may contribute to the association between cancer progression and thrombosis. Hypoxia and HIF-mediated mechanisms that regulate this positive correlation are currently under scrutiny in our laboratory.

In summary, endothelial HIF regulates cancer progression and is therefore an attractive target for novel adjunctive cancer therapies. The effects of endothelial HIF signalling on metastasis are isoform dependent, however, so these therapies should aim to target the HIF pathway in an isoform-specific manner.

Acknowledgments RSJ is supported by a Wellcome Trust principal investigator fellowship.

Conflict of interest The authors declare they have no conflict of interest.

\section{References}

1. Tatum JL, Kelloff GJ, Gillies RJ, Arbeit JM, Brown JM, Chao KS, Chapman JD, Eckelman WC, Fyles AW, Giaccia AJ, Hill RP, Koch CJ, Krishna MC, Krohn KA, Lewis JS, Mason RP, Melillo G, Padhani AR, Powis G, Rajendran JG, Reba R, Robinson SP, Semenza GL, Swartz HM, Vaupel P, Yang D, Croft B, Hoffman J, Liu G, Stone H, Sullivan D. Hypoxia: importance in tumor biology, noninvasive measurement by imaging, and value of its measurement in the management of cancer therapy. Int $\mathbf{J}$ Radiat Biol. 2006;82:699-757.

2. Branco-Price C, Zhang N, Schnelle M, Evans C, Katschinski DM, Liao D, Ellies L, Johnson RS. Endothelial cell HIF-1alpha and HIF-2alpha differentially regulate metastatic success. Cancer Cell. 2012;21:52-65.

3. Doedens AL, Stockmann C, Rubinstein MP, Liao D, Zhang N, DeNardo DG, Coussens LM, Karin M, Goldrath AW, Johnson RS. Macrophage expression of hypoxia-inducible factor-1 alpha suppresses T-cell function and promotes tumor progression. Cancer Res. 2010;70:7465-75.

4. Zhong H, De Marzo AM, Laughner E, Lim M, Hilton DA, Zagzag D, Buechler P, Isaacs WB, Semenza GL, Simons JW. Overexpression of hypoxia-inducible factor 1alpha in common human cancers and their metastases. Cancer Res. 1999;59: $5830-5$. metastasis. Conversely, tumour formation stimulates an endothelial HIF-mediated hypoxic response that leads to expression of coagulants and increased thrombus formation

5. Licht AH, Muller-Holtkamp F, Flamme I, Breier G. Inhibition of hypoxia-inducible factor activity in endothelial cells disrupts embryonic cardiovascular development. Blood. 2006;107: 584-90.

6. Ten VS, Pinsky DJ. Endothelial response to hypoxia: physiologic adaptation and pathologic dysfunction. Curr Opin Crit Care. 2002;8:242-50.

7. Ogawa S, Gerlach H, Esposito C, Pasagian-Macaulay A, Brett J, Stern D. Hypoxia modulates the barrier and coagulant function of cultured bovine endothelium. Increased monolayer permeability and induction of procoagulant properties. J Clin Invest. 1990;85: $1090-8$.

8. Folkman J. Looking for a good endothelial address. Cancer Cell. 2002;1:113-5.

9. St Croix B, Rago C, Velculescu V, Traverso G, Romans KE, Montgomery E, Lal A, Riggins GJ, Lengauer C, Vogelstein B, Kinzler KW. Genes expressed in human tumor endothelium. Science. 2000;289:1197-202.

10. Lu C, Bonome T, Li Y, Kamat AA, Han LY, Schmandt R, Coleman RL, Gershenson DM, Jaffe RB, Birrer MJ, Sood AK. Gene alterations identified by expression profiling in tumorassociated endothelial cells from invasive ovarian carcinoma. Cancer Res. 2007;67:1757-68.

11. Hewett P, Popplewell A, Finney H, Murray JC. Changes in microvessel endothelial cell gene expression in an in vitro human breast tumour endothelial cell model. Angiogenesis. 1999;3:221-9.

12. Hobson B, Denekamp J. Endothelial proliferation in tumours and normal tissues: continuous labelling studies. Br J Cancer. 1984; 49:405-13.

13. Toffoli S, Michiels C. Intermittent hypoxia is a key regulator of cancer cell and endothelial cell interplay in tumours. FEBS J. 2008:275:2991-3002.

14. Martinive P, Defresne F, Bouzin C, Saliez J, Lair F, Gregoire V, Michiels C, Dessy C, Feron O. Preconditioning of the tumor vasculature and tumor cells by intermittent hypoxia: implications for anticancer therapies. Cancer Res. 2006;66:11736-44.

15. Kanaan A, Farahani R, Douglas RM, Lamanna JC, Haddad GG. Effect of chronic continuous or intermittent hypoxia and reoxygenation on cerebral capillary density and myelination. Am J Physiol Regul Integr Comp Physiol. 2006;290:R1105-14.

16. Michiels C, Arnould T, Remacle J. Endothelial cell responses to hypoxia: initiation of a cascade of cellular interactions. Biochim Biophys Acta. 2000;1497:1-10.

17. Shreeniwas R, Koga S, Karakurum M, Pinsky D, Kaiser E, Brett J, Wolitzky BA, Norton C, Plocinski J, Benjamin W, et al. Hypoxia-mediated induction of endothelial cell interleukin-1 alpha. An autocrine mechanism promoting expression of leukocyte adhesion molecules on the vessel surface. J Clin Invest. 1992;90:2333-9. 
18. Adams DH, Shaw S. Leucocyte-endothelial interactions and regulation of leucocyte migration. Lancet. 1994;343:831-6.

19. Wang CY, Naka Y, Liao H, Oz MC, Springer TA, GutierrezRamos JC, Pinsky DJ. Cardiac graft intercellular adhesion molecule-1 (ICAM-1) and interleukin-1 expression mediate primary isograft failure and induction of ICAM-1 in organs remote from the site of transplantation. Circ Res. 1998;82:762-72.

20. Toda K, Kayano K, Karimova A, Naka Y, Fujita T, Minamoto K, Wang CY, Pinsky DJ. Antisense intercellular adhesion molecule1 (icam-1) oligodeoxyribonucleotide delivered during organ preservation inhibits posttransplant icam-1 expression and reduces primary lung isograft failure. Circ Res. 2000;86:166-74.

21. Oz MC, Liao H, Naka Y, Seldomridge A, Becker DN, Michler RE, Smith CR, Rose EA, Stern DM, Pinsky DJ. Ischemia-induced interleukin-8 release after human heart transplantation. A potential role for endothelial cells. Circulation. 1995;92: II428-432.

22. Faller DV. Endothelial cell responses to hypoxic stress. Clin Exp Pharmacol Physiol. 1999;26:74-84.

23. Faller DV, Weng H, Choi SY. Activation of collagenase IV gene expression and enzymatic activity by the moloney murine leukemia virus long terminal repeat. Virology. 1997;227:331-42.

24. Finkenzeller G, Marme D, Weich HA, Hug H. Platelet-derived growth factor-induced transcription of the vascular endothelial growth factor gene is mediated by protein kinase C. Cancer Res. 1992;52:4821-3.

25. Fischer C, Mazzone M, Jonckx B, Carmeliet P. Flt1 and its ligands vegfb and plgf: drug targets for anti-angiogenic therapy? Nat Rev Cancer. 2008;8:942-56.

26. Ribatti D. The discovery of the placental growth factor and its role in angiogenesis: a historical review. Angiogenesis. 2008;11: 215-21.

27. Bottomley MJ, Webb NJ, Watson CJ, Holt L, Bukhari M, Denton J, Freemont AJ, Brenchley PE. Placenta growth factor (PLGF) induces vascular endothelial growth factor (VEGF) secretion from mononuclear cells and is co-expressed with vegf in synovial fluid. Clin Exp Immunol. 2000;119:182-8.

28. Marcellini M, De Luca N, Riccioni T, Ciucci A, Orecchia A, Lacal PM, Ruffini F, Pesce M, Cianfarani F, Zambruno G, Orlandi A, Failla CM. Increased melanoma growth and metastasis spreading in mice overexpressing placenta growth factor. Am J Pathol. 2006;169:643-54.

29. Roy H, Bhardwaj S, Babu M, Jauhiainen S, Herzig KH, Bellu AR, Haisma HJ, Carmeliet P, Alitalo K, Yla-Herttuala S. Adenovirus-mediated gene transfer of placental growth factor to perivascular tissue induces angiogenesis via upregulation of the expression of endogenous vascular endothelial growth factor-A. Hum Gene Ther. 2005;16:1422-8.

30. Grose R, Dickson C. Fibroblast growth factor signaling in tumorigenesis. Cytokine Growth Factor Rev. 2005;16:179-86.

31. Fowler DJ, Nicolaides KH, Miell JP. Insulin-like growth factor binding protein-1 (IGFBP-1): a multifunctional role in the human female reproductive tract. Hum Reprod Update. 2000;6:495-504.

32. Ferrara N, Gerber HP, LeCouter J. The biology of VEGF and its receptors. Nat Med. 2003;9:669-76.

33. Namiki A, Brogi E, Kearney M, Kim EA, Wu T, Couffinhal T, Varticovski L, Isner JM. Hypoxia induces vascular endothelial growth factor in cultured human endothelial cells. J Biol Chem. 1995;270:31189-95.

34. Pepper MS, Ferrara N, Orci L, Montesano R. Vascular endothelial growth factor (VEGF) induces plasminogen activators and plasminogen activator inhibitor-1 in microvascular endothelial cells. Biochem Biophys Res Commun. 1991;181:902-6.

35. Gerber HP, McMurtrey A, Kowalski J, Yan M, Keyt BA, Dixit V, Ferrara N. Vascular endothelial growth factor regulates endothelial cell survival through the phosphatidylinositol $3^{\prime}$-kinase/akt signal transduction pathway. Requirement for flk-1/kdr activation. J Biol Chem. 1998;273:30336-43.

36. Hattori K, Dias S, Heissig B, Hackett NR, Lyden D, Tateno M, Hicklin DJ, Zhu Z, Witte L, Crystal RG, Moore MA, Rafii S. Vascular endothelial growth factor and angiopoietin-1 stimulate postnatal hematopoiesis by recruitment of vasculogenic and hematopoietic stem cells. J Exp Med. 2001;193:1005-14.

37. Barleon B, Sozzani S, Zhou D, Weich HA, Mantovani A, Marme D. Migration of human monocytes in response to vascular endothelial growth factor (VEGF) is mediated via the VEGF receptor flt-1. Blood. 1996;87:3336-43.

38. Clauss M, Gerlach M, Gerlach H, Brett J, Wang F, Familletti PC, Pan YC, Olander JV, Connolly DT, Stern D. Vascular permeability factor: a tumor-derived polypeptide that induces endothelial cell and monocyte procoagulant activity, and promotes monocyte migration. J Exp Med. 1990;172:1535-45.

39. Mumby SM, Abbott-Brown D, Raugi GJ, Bornstein P. Regulation of thrombospondin secretion by cells in culture. J Cell Physiol. 1984;120:280-8.

40. Dixit VM, Haverstick DM, O'Rourke KM, Hennessy SW, Grant GA, Santoro SA, Frazier WA. A monoclonal antibody against human thrombospondin inhibits platelet aggregation. Proc Natl Acad Sci USA. 1985;82:3472-6.

41. O'Shea KS, Dixit VM. Unique distribution of the extracellular matrix component thrombospondin in the developing mouse embryo. J Cell Biol. 1988;107:2737-48.

42. Karakurum M, Shreeniwas R, Chen J, Pinsky D, Yan SD, Anderson M, Sunouchi K, Major J, Hamilton T, Kuwabara K, et al. Hypoxic induction of interleukin-8 gene expression in human endothelial cells. J Clin Invest. 1994;93:1564-70.

43. Tang N, Wang L, Esko J, Giordano FJ, Huang Y, Gerber HP, Ferrara N, Johnson RS. Loss of HIF-1alpha in endothelial cells disrupts a hypoxia-driven VEGF autocrine loop necessary for tumorigenesis. Cancer Cell. 2004;6:485-95.

44. Skuli N, Majmundar AJ, Krock BL, Mesquita RC, Mathew LK, Quinn ZL, Runge A, Liu L, Kim MN, Liang J, Schenkel S, Yodh AG, Keith B, Simon MC. Endothelial HIF- $2 \alpha$ regulates murine pathological angiogenesis and revascularization processes. J Clin Invest. 2012;122(4):1427-43.

45. Skuli N, Liu L, Runge A, Wang T, Yuan L, Patel S, Iruela-Arispe L, Simon MC, Keith B. Endothelial deletion of hypoxia-inducible factor-2alpha (HIF-2alpha) alters vascular function and tumor angiogenesis. Blood. 2009;114:469-77.

46. Zetter BR. Angiogenesis and tumor metastasis. Annu Rev Med. 1998;49:407-24.

47. Butler TP, Gullino PM. Quantitation of cell shedding into efferent blood of mammary adenocarcinoma. Cancer Res. 1975;35:512-6.

48. Wakefield TW, Myers DD, Henke PK. Mechanisms of venous thrombosis and resolution. Arterioscler Thromb Vasc Biol. 2008; 28:387-91.

49. Wu Q, Zhao Z. Inhibition of PAI-1: a new anti-thrombotic approach. Curr Drug Targets Cardiovasc Haematol Disord. 2002; 2:27-42.

50. Gupta GP, Massague J. Platelets and metastasis revisited: a novel fatty link. J Clin Invest. 2004;114:1691-3.

51. Belting M, Ahamed J, Ruf W. Signaling of the tissue factor coagulation pathway in angiogenesis and cancer. Arterioscler Thromb Vasc Biol. 2005;25:1545-50.

52. Gertler JP, Weibe DA, Ocasio VH, Abbott WM. Hypoxia induces procoagulant activity in cultured human venous endothelium. J Vasc Surg. 1991;13:428-33.

53. Hamer JD, Malone PC, Silver IA. The $\mathrm{PO}_{2}$ in venous valve pockets: its possible bearing on thrombogenesis. Br J Surg. 1981; 68:166-70.

54. Evans CE, Humphries J, Mattock K, Waltham M, Wadoodi A, Saha P, Modarai B, Maxwell PH, Smith A. Hypoxia and 
upregulation of hypoxia-inducible factor 1 \{alpha\} stimulate venous thrombus recanalization. Arterioscler Thromb Vasc Biol. 2010;30:2443-51.

55. Rickles FR, Patierno S, Fernandez PM. Tissue factor, thrombin, and cancer. Chest. 2003;124:58S-68S.

56. Boccaccio C, Comoglio PM. Genetic link between cancer and thrombosis. J Clin Oncol. 2009;27:4827-33.

57. Falanga A, Marchetti M, Vignoli A, Balducci D. Clotting mechanisms and cancer: implications in thrombus formation and tumor progression. Clin Adv Hematol Oncol. 2003;1:673-8.

58. Im JH, Fu W, Wang H, Bhatia SK, Hammer DA, Kowalska MA, Muschel RJ. Coagulation facilitates tumor cell spreading in the pulmonary vasculature during early metastatic colony formation. Cancer Res. 2004;64:8613-9.

59. Palumbo JS, Kombrinck KW, Drew AF, Grimes TS, Kiser JH, Degen JL, Bugge TH. Fibrinogen is an important determinant of the metastatic potential of circulating tumor cells. Blood. 2000; 96:3302-9.

60. Palumbo JS, Talmage KE, Massari JV, La Jeunesse CM, Flick MJ, Kombrinck KW, Jirouskova M, Degen JL. Platelets and fibrin(ogen) increase metastatic potential by impeding natural killer cell-mediated elimination of tumor cells. Blood. 2005;105: 178-85.

61. Varki A. Trousseau's syndrome: multiple definitions and multiple mechanisms. Blood. 2007;110:1723-9.

62. Rundqvist H, Johnson RS. Hypoxia and metastasis in breast cancer. Curr Top Microbiol Immunol. 2010;345:121-39.

63. Rofstad EK, Tunheim SH, Mathiesen B, Graff BA, Halsor EF, Nilsen K, Galappathi K. Pulmonary and lymph node metastasis is associated with primary tumor interstitial fluid pressure in human melanoma xenografts. Cancer Res. 2002;62:661-4.

64. Coulet F, Nadaud S, Agrapart M, Soubrier F. Identification of hypoxia-response element in the human endothelial nitric-oxide synthase gene promoter. J Biol Chem. 2003;278:46230-40.

65. Palmer RM, Ferrige AG, Moncada S. Nitric oxide release accounts for the biological activity of endothelium-derived relaxing factor. Nature. 1987;327:524-6.
66. Nakaki T, Nakayama M, Kato R. Inhibition by nitric oxide and nitric oxide-producing vasodilators of DNA synthesis in vascular smooth muscle cells. Eur J Pharmacol. 1990;189:347-53.

67. Garg UC, Hassid A. Nitric oxide-generating vasodilators and 8-bromo-cyclic guanosine monophosphate inhibit mitogenesis and proliferation of cultured rat vascular smooth muscle cells. J Clin Invest. 1989;83:1774-7.

68. Garg UC, Hassid A. Nitric oxide-generating vasodilators inhibit mitogenesis and proliferation of BALB/C $3 \mathrm{~T} 3$ fibroblasts by a cyclic GMP-independent mechanism. Biochem Biophys Res Commun. 1990;171:474-9.

69. Rossig L, Fichtlscherer B, Breitschopf K, Haendeler J, Zeiher AM, Mulsch A, Dimmeler S. Nitric oxide inhibits caspase- 3 by S-nitrosation in vivo. J Biol Chem. 1999;274:6823-6.

70. Cooke JP. No and angiogenesis. Atheroscler Suppl. 2003;4: 53-60.

71. Kourembanas S, McQuillan LP, Leung GK, Faller DV. Nitric oxide regulates the expression of vasoconstrictors and growth factors by vascular endothelium under both normoxia and hypoxia. J Clin Invest. 1993;92:99-104.

72. Millar TM, Phan V, Tibbles LA. Ros generation in endothelial hypoxia and reoxygenation stimulates map kinase signaling and kinase-dependent neutrophil recruitment. Free Radic Biol Med. 2007;42:1165-77.

73. Gerald D, Berra E, Frapart YM, Chan DA, Giaccia AJ, Mansuy D, Pouyssegur J, Yaniv M, Mechta-Grigoriou F. Jund reduces tumor angiogenesis by protecting cells from oxidative stress. Cell. 2004;118:781-94.

74. Guzy RD, Hoyos B, Robin E, Chen H, Liu L, Mansfield KD, Simon MC, Hammerling U, Schumacker PT. Mitochondrial complex III is required for hypoxia-induced ros production and cellular oxygen sensing. Cell Metab. 2005;1:401-8.

75. Guzy RD, Schumacker PT. Oxygen sensing by mitochondria at complex III: the paradox of increased reactive oxygen species during hypoxia. Exp Physiol. 2006;91:807-19. 